\title{
PCR Primers for Microsatellite Loci in Tuna Species of the Genus Thunnus and its Application for Population Genetic Study
}

\author{
Motohiro Takagi, ${ }^{* 1,+1}$ Teturo Okamura, ${ }^{* 1}$ Seinen Chow, ${ }^{* 2}$ \\ and Nobuhiko Taniguchi ${ }^{* 1, \dagger 2}$ \\ ${ }^{* 1}$ Department of Cultural Fisheries, Faculty of Agriculture, Kochi University, \\ Monobe, Nankoku, Kochi 783-8502, Japan \\ ${ }^{*}$ National Research Institute of Far Seas Fisheries, Orido, Shimizu 424-8633, Japan
}

(Received December 28, 1998)

\begin{abstract}
Microsatellite loci were isolated from a size-selected genomic library of Pacific northern tuna Thunnus thynnus orientalis, and PCR primer sets to amplify four loci were designed. Investigation on genetic polymorphism at these loci in the Pacific northern bluefin tuna sample $(n=35-40)$ revealed high degree of length polymorphisms in all loci, in which number of alleles per locus ranged from 8 to 23 and observed heterozygosity from 0.533 to 1 . These primer sets were applied to Atlantic northern bluefin tuna $T$. $t$. thynnus, albacore $T$. alalunga, bigeye tuna $T$. obesus and yellowfin tuna $T$. albacares, detecting polymorphism in all loci comparable with those of Pacific northern bluefin tuna. Significant differences in the allele frequency were observed between Pacific and Atlantic northern bluefin tuna samples. These primer sets developed for Pacific northern bluefin tuna appeared to be useful for amplifying homologous microsatellite loci in the other Thunnus tuna species, and may have great potential as indicators for genetic variability within and between samples of tuna species of the genus Thunnus.
\end{abstract}

Key words: microsatellite, Thunnus tuna species, genetic variability, population genetics

All tuna species of the genus Thunnus are important for commercial fisheries. Clarifying their stock structure may be very important information for proper stock assessment and management strategy. Molecular genetic approaches have been available as tools for investigating fish stock structure. Allozyme analysis has been employed for investigating stock structure of Atlantic northern bluefin tuna Thunnus thynnus thynnus ${ }^{1,2)}$ and yellowfin tuna $T$. albacares. ${ }^{3)}$ However, these investigations have failed to find substantial genetic differentiation among local samples of these tuna species because of insufficient genetic polymorphism in allozyme gene markers. Mitochondrial DNA analyses revealed large genetic differentiation between Atlantic and Pacific northern bluefin tuna populations. However, mtDNA analysis alone has no power to cope with population mixture nor can they verify whether a local sample is from a single panmictic population. Recently, nucleic microsatellites consisting of tandem arrays of di-, tri-, or tetra- nucleotide sequences flanked by regions of unique DNA sequences ${ }^{4)}$ have been shown to be highly polymorphic particularly in fish. ${ }^{\text {s) }}$ Microsatellites are among the most likely to confirm with the assumption of neutrality and have proved its power for distinguishing geographically isolated subpopulations. ${ }^{6}$ ) Few studies have been carried out on microsatellite variation analysis of Thunnus species (Atlantic northern bluefin tuna T. thynnus thynnus)."

In the present study, we report the isolation of microsatellite loci of the Pacific northern bluefin tuna
Thunnus thynnus orientalis and PCR primers designed to amplify these microsatellite loci. These PCR primers were applied to the other tuna species of the genus Thunnus, and genetic differentiation within species was investigated.

\section{Materials and Methods}

\section{Fish Samples and DNA Preparation}

Collection information of fish samples used are presented in Table 1. For constructing genomic DNA library, high molecular weight DNA samples were extracted from blood of three fresh Pacific northern bluefin tuna caught off Japan. Crude DNA samples were extracted from frozen or ethanol-preserved muscle tissues of Atlantic northern bluefin tuna $T$. thynnus thynnus, albacore $T$. alalunga, bigeye tuna $T$. obesus and yellowfin tuna $T$. albacares. The standard SDS-phenol/chloroform procedures ${ }^{8)}$ were used for both tissues. Extracted DNA were disolved in TE buffer and stored at $4^{\circ} \mathrm{C}$ prior to PCR analysis.

\section{Isolation of Microsatellites from Bluefin Tuna}

A genomic library was constructed by using basically the same procedure as Takagi et al. $\left.{ }^{9}\right)$ High molecular weight DNA samples extracted from 3 individuals of Pacific northern bluefin tuna were pooled, digested with HaeIII, HincII and RsaI and electrophoresed on agarose gel. Fragments ranged between 400 and 2000 bp were excised and subjected to phenol/chloroform extraction. The digested DNA samples were ligated into the SmaI site of PUC18

\footnotetext{
t1 Present address: Ono Limnological Station, National Fisheries University, Ono, Ube, Yamaguchi 754-1311, Japan.

t2 Corresponding author, Present address: Laboratory of Applied Population Genetics, Graduate School of Agriculture Science, Tohoku University, Amamiya, Aoba, Sendai 981-8555, Japan.
} 
plasmid vector which was used for transforming DH5o starin of $E$. coli. Positive transformants were screened with $\left[{ }^{32} \mathrm{P}\right]$-labeled $(\mathrm{GT})_{15}$ synthetic oligonucleotide. Sequencing of positive clones was performed by 373 DNA sequencer (Applied Biosystems Inc.) using a Taq dye-terminator cycle sequencing kit (Perkin-Elmer Cetus, Norfolk) with universal M13 reverse and forward primers.

\section{Detection of Polymorphism by PCR and PAG Electropho- resis}

Primers were designed to hybridize with unique regions flanking the core sequences of the microsatellites using Oligo $^{\mathrm{TM}}$ (N. B. I. Inc.). The reverse primer was 5'endlabelled with $\left[\gamma^{32} \mathrm{P}\right] \mathrm{ATP}$. PCR was carried out using a MJ Thermal cycler (MJ research Inc.). The $6 \mu l$ of reaction contained 10ng of template DNA, $2.5 \mu \mathrm{M}$ each unlabeled primer, $0.25 \mu \mathrm{M}$ labeled reverse primer, $10 \mathrm{mM}$ Tris- $\mathrm{HCl}$ (pH 8.3), $1 \mathrm{mM} \mathrm{MgCl}_{2}, 50 \mathrm{mM} \mathrm{KCl}, 0.01 \%$ gelatin, 1.75 $\mu \mathrm{M}$ each dNTPs and 0.25 unit of Taq Polymerase (Applied Biosystems Inc.). The PCR was programmed for 7 cycles of initial amplification (denaturation at $94^{\circ} \mathrm{C}$ for $1 \mathrm{~min}$, annealing at $52^{\circ} \mathrm{C}$ for $30 \mathrm{~s}$, and extension at $72^{\circ} \mathrm{C}$ for $30 \mathrm{~s}$ ) followed by 33 cycles of secondary amplification (denaturation at $90^{\circ} \mathrm{C}$ for $30 \mathrm{~s}$, annealing at $52^{\circ} \mathrm{C}$ for $30 \mathrm{~s}$, and exten-

Table 1. Catch locality, date and mean fork length of the tuna species used in the study

\begin{tabular}{lccc}
\multicolumn{1}{c}{ Area sample } & $(n)$ & Date & $\begin{array}{c}\text { Mean fork } \\
\text { length } \pm \text { SD }\end{array}$ \\
\hline $\begin{array}{l}\text { Pacific northern bluefin tuna } \\
\text { Off Japan (Tosa Bay) }\end{array}$ & $(48)$ & $\begin{array}{c}26 \text { Jul. } \\
29 \text { Aug. } 1995\end{array}$ & $20.7 \pm 1.6$ \\
$\begin{array}{l}\text { Atlantic northern bluefin tuna } \\
\text { N. W. Atlantic } \\
\text { (42N, S2-63W) }\end{array}$ & (48) & Nov.-Dec. 1992 & $193.2 \pm 44.9$ \\
$\begin{array}{l}\text { Mediterranean } \\
\text { (Messina Strait) }\end{array}$ & (39) & Mar.-May. 1994 & Adults \\
$\begin{array}{l}\text { Albacore } \\
\text { E. Australia } \\
\text { (18-20S, 154-155E) }\end{array}$ & & & \\
$\begin{array}{l}\text { Bigeye tuna } \\
\text { Off Philippines } \\
\text { (Celebes Sea) }\end{array}$ & (32) & $4-7$ Aug. 1993 & $9.5 \pm 0.5$ \\
$\begin{array}{l}\text { Yellowfin tuna } \\
\text { Off Philippines } \\
\text { (Celebes Sea) }\end{array}$ & (32) & 26,27 Jul. 1993 & $28.1 \pm 4.0$ \\
\hline
\end{tabular}

sion at $72^{\circ} \mathrm{C}$ for $30 \mathrm{~s}$ ). Following amplification the sample was mixed with an equal volume of denaturing stop dye (Pharmacia Inc.), heated at $95^{\circ} \mathrm{C}$ for $15 \mathrm{~min}$, and electrophoresed on $8 \%$ polyacrylamide gel ( $7 \mathrm{M}$ urea, $8 \%$ acrylamide). Drying on gels and autoradiography were as described in Sambrook et al. ${ }^{10)}$ Alleles of each locus were sized relative to a $\mathrm{M} 13$ sequence ladder. ${ }^{11)}$ Designation of loci and alleles were given by following the abbreviated scientific name and fragment size. ${ }^{12)}$ Genotype frequencies in each sample at each locus were tested for conformity to Hardy-Weinberg equilibrium ${ }^{13)}$ using Arlequin version $1.1 .^{14)}$ Allele frequencies were then used to calculate population pairwise FSTs by Arlequin version 1.1 and Nei's genetic distance ${ }^{15)}$ by Phylip-PC version 3.57c. ${ }^{16)}$

\section{Results}

\section{Detection of Microsatellite Loci and Genetic diversity in Northern Bluefin Tuna}

Among 41 positive clones obtained, presence of microsatellite was directly confirmed in 10 clones by partial nucleotide sequencing. Among 10 PCR primer sets designed to flank these microsatellite regions, fragment amplification was observed in seven primer sets, and scorable and constant amplification of DNA fragments were obtained in 4 primer sets. The nucleotide sequences of 4 sets of PCR primers to amplify these four gene loci (designated Ttho- $1^{*},-4^{*},-6^{*}$ and $-7^{*}$ ) are presented in Table 2 . A highly polymorphic profile in a locus $\left(\right.$ Ttho- $\left.6^{*}\right)$ of Pacific northern bluefin tuna is shown in Fig. 1.

To estimate levels of variation at each microsatellite locus, three samples of northern bluefin tuna (one Pacific and two Atlantic) were analyzed. All these 4 loci were found to be highly polymorphic, in which observed heterozygosity (ho) ranged from 0.538 at $T t h o-I^{*}$ of N. W. Atlantic sample to 1 at Ttho- $7^{*}$ of off Japan and Mediterranean samples (Table 3 ). Similar variations were observed among samples, in which Ttho- $6^{*}$ had the largest number of alleles (15 to 23 ) followed by $T$ tho- $7^{*}$ and $-4^{*}$ (10 to 15$)$, and Ttho- $I^{*}$ having the least number of alleles (6 and 8 ). No significant discrepancy between observed and expected number of genotypes was observed in all loci, as well as between observed (ho) and expected (he) heterozygosities. Mean heterozygosity ( $\mathrm{Ho}$ ) was very high ranging from 0.701 to 0.865 , and no large diffference in the mean heter-

Table 2. Nucleotide sequence and genetic variability of four Thunnus thynnus microsatellite PCR primers

\begin{tabular}{|c|c|c|c|c|c|c|c|}
\hline Locus & $\begin{array}{l}\text { Repeat } \\
\text { motif*a }\end{array}$ & Primer sequence $\left(5^{\prime}-3^{\prime}\right)^{* b}$ & $\begin{array}{l}\text { Annealing } \\
\text { temp. }{ }^{* c}\end{array}$ & $\begin{array}{l}\text { No. of } \\
\text { samples }\end{array}$ & $\begin{array}{l}\text { No. of } \\
\text { alleles }\end{array}$ & $\begin{array}{l}\text { Size } \\
(\mathrm{bp})^{*_{d}}\end{array}$ & $\begin{array}{l}\text { Hetero- } \\
\text { zygosity }\end{array}$ \\
\hline \multirow[t]{2}{*}{ Ttho-1* } & (GT) & F: AAACGCTCCAGGCAAATGAC & 50 & (39) & 8 & $175-189$ & 0.533 \\
\hline & & R: CATAGCACACCCATAGACAC & & & & & \\
\hline \multirow[t]{2}{*}{ Ttho-4* } & (CA) & F: CCTTCATCTTCAGTCCCATC & 52 & (39) & 12 & $134-164$ & 0.811 \\
\hline & & R: CTGTTCATCTGTTCGCCC & & & & & \\
\hline \multirow[t]{2}{*}{ Ttho- $6^{*}$} & (CA) & F: TTCTGCTTCTTTCTTCTGG & 52 & (35) & 23 & $121-219$ & 0.924 \\
\hline & & R: GAAAACACAGGGATTATGG & & & & & \\
\hline \multirow[t]{2}{*}{ Ttho- $7^{*}$} & (CA) & F: ACTGGATGAAAGGCGATTAC & 52 & (40) & 15 & $198-230$ & 0.884 \\
\hline & & R: ACAGAGGAGCATAACAGAAAC & & & & & \\
\hline
\end{tabular}

$*_{\mathrm{a}}=$ Core repeat motif from cloned Thunnus thynnus orientalis sequence.

$*_{b}=F$ and $\mathrm{R}$ refer to forward and reverse primer sequence respectively.

$*_{G}=$ PCR annealing temperatures were optimized for Thunnus thymus orientalis.

${ }^{*}=$ Estimated size of the PCR fragment when compared with M13 sequence fragmentes of known length.

$*_{e}=$ Estimated heterozygosity. 


\section{Ttho-6* \\ Pacific northern bluefin tuna}

\section{M13 mp18}

\section{A C G T}

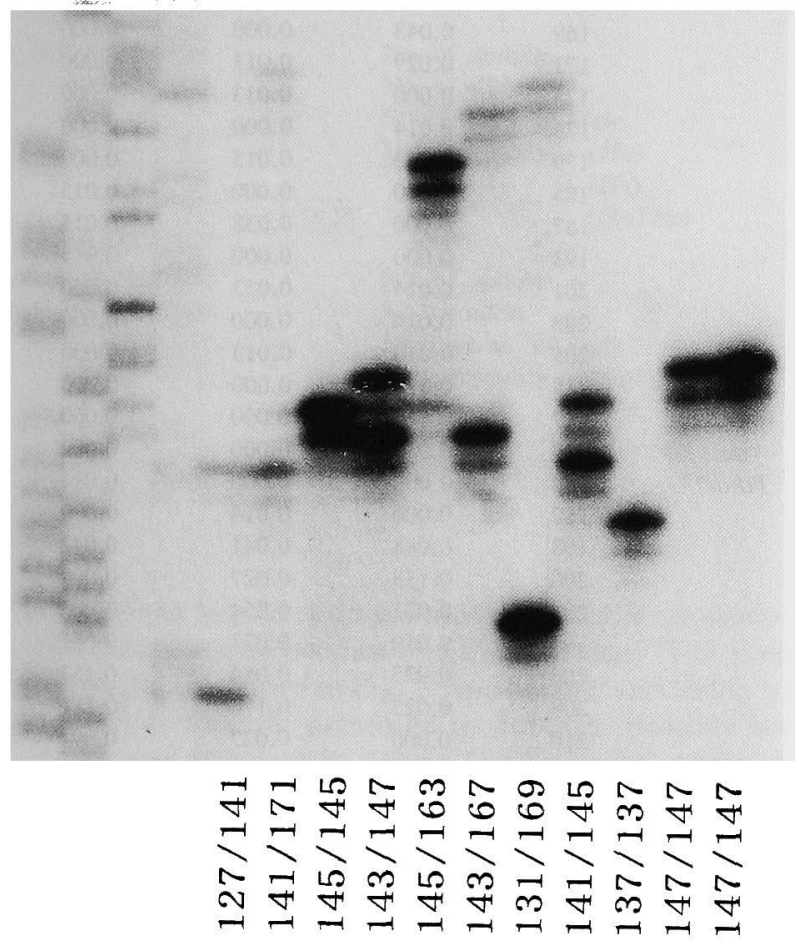

Fig. 1. Microsatellite variation in Ttho- $6^{*}$ locus of Thunnus thynnus orientalis. The size standard is a sequence ladder of M13 mp18.
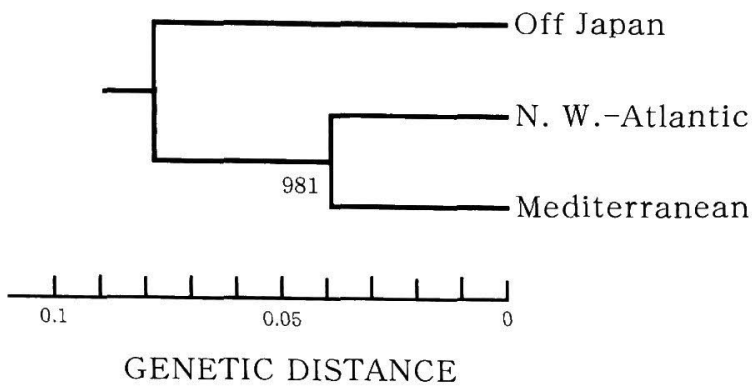

Fig. 2. UPGMA dendrogram and bootstrap value of Pacific northern bluefin tuna and 2 samples of Atlantic northern bluefin tuna.

ozygosity was observed among these northern bluefin tuna samples.

Allele frequencies at these four loci of three northern bluefin tuna samples are presented in Table 4. All samples shared the most common allele in all loci but Ttho- $6^{*}$. Significant difference in allele frequencies was observed between the off Japan and N. W. Atlantic samples $\left(F_{\mathrm{ST}}=0.024, P<0.001\right)$ and between the off Japan and Mediterranean samples $\left(F_{\mathrm{ST}}=0.029, P<0.001\right)$, while no significant difference was observed between N. W. Atlantic and Mediterranean samples $\left(F_{\mathrm{ST}}=0.002, P>0.294\right)$. Allele frequencies were used to calculate genetic distances between samples and a UPGMA dendrogram was constructed, showing close relationships between N. W. Atlantic and Mediterranean samples of Atlantic northern bluefin tuna and distinct status of Pacific northern bluefin tuna sample supported by considerably high bootstrap value (981 out of 1,000 randomization) (Fig. 2).

\section{Application of PCR Primers to Different Thunnus Tuna} Species

All four sets of PCR primers were found to successfully amplify scorable fragment patterns also in the other three

Table 3. Genetic variability for 4 microsatellite loci surveyed for northern bluefin tuna used in the study

\begin{tabular}{|c|c|c|c|c|c|c|}
\hline & & Ttho-1* & Ttho- $4^{*}$ & Ttho- $6^{*}$ & Ttho- $7^{*}$ & Mean \\
\hline \multicolumn{7}{|c|}{ Pacific northern bluefin tuna } \\
\hline \multirow{6}{*}{$\begin{array}{l}\text { Off Japan } \\
\text { (Tosa Bay) }\end{array}$} & No. of samples & (39) & (39) & (35) & $(40)$ & \\
\hline & No. of allele & 8 & 12 & 23 & 15 & 14.5 \\
\hline & Effective no. of allele ${ }^{*_{1}}$ & 2.13 & 5.29 & 13.16 & 8.62 & 7.30 \\
\hline & \multirow[t]{3}{*}{ Heterozygosity } & 0.564 & 0.923 & 0.886 & 1.000 & 0.843 \\
\hline & & 0.531 & 0.811 & 0.924 & 0.884 & 0.788 \\
\hline & & 1.058 & 1.138 & 0.959 & 1.131 & 1.072 \\
\hline \multicolumn{7}{|c|}{ Atlantic northern bluefin tuna } \\
\hline \multirow{6}{*}{$\begin{array}{l}\text { N. W. Atlantic } \\
\quad(42 \mathrm{~N}, 52-63 \mathrm{~W})\end{array}$} & No. of samples & (39) & $(38)$ & (39) & (37) & \\
\hline & No. of allele & 6 & 10 & 21 & 15 & 13.0 \\
\hline & Effective no. of allele & 2.73 & 4.39 & 8.13 & 6.58 & 5.46 \\
\hline & \multirow[t]{3}{*}{ Heterozygosity } & 0.538 & 0.684 & 0.744 & 0.838 & 0.701 \\
\hline & & 0.633 & 0.772 & 0.877 & 0.848 & 0.783 \\
\hline & & 0.850 & 0.886 & 0.848 & 0.988 & 0.893 \\
\hline \multirow{6}{*}{$\begin{array}{l}\text { Mediterranean } \\
\text { (Messina Strait) }\end{array}$} & No. of samples & $(38)$ & $(38)$ & (34) & $(36)$ & \\
\hline & No. of allele & 6 & 12 & 15 & 12 & 11.3 \\
\hline & Effective no. of allele & 2.73 & 6.58 & 7.35 & 8.77 & 6.36 \\
\hline & \multirow[t]{3}{*}{ Heterozygosity } & 0.684 & 0.921 & 0.853 & 1.000 & 0.865 \\
\hline & & 0.633 & 0.848 & 0.864 & 0.886 & 0.808 \\
\hline & & 1.081 & 1.086 & 0.973 & 1.129 & 1.067 \\
\hline
\end{tabular}

$*^{*}:=1 /(1-H e)$. 
Table 4. Allele frequency for 4 microsatellite loci surveyed for Northern bluefin tuna used in the study

\begin{tabular}{|c|c|c|c|c|}
\hline \multirow{2}{*}{ Locus } & \multirow{2}{*}{$\begin{array}{l}\text { Allele } \\
\text { (bp) }\end{array}$} & \multirow{2}{*}{ 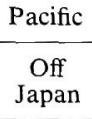 } & \multicolumn{2}{|c|}{ Atlantic } \\
\hline & & & $\begin{array}{l}\text { N. W. } \\
\text { Atlantic }\end{array}$ & $\begin{array}{c}\text { Medi- } \\
\text { terranean }\end{array}$ \\
\hline \multirow[t]{9}{*}{ Ttho-I* } & 175 & 0.013 & 0.000 & 0.000 \\
\hline & 177 & 0.051 & 0.026 & 0.013 \\
\hline & 179 & 0.115 & 0.192 & 0.211 \\
\hline & 181 & 0.667 & 0.526 & 0.526 \\
\hline & 183 & 0.077 & 0.231 & 0.211 \\
\hline & 185 & 0.026 & 0.000 & 0.026 \\
\hline & 187 & 0.013 & 0.000 & 0.000 \\
\hline & 189 & 0.038 & 0.013 & 0.013 \\
\hline & 193 & 0.000 & 0.013 & 0.000 \\
\hline \multirow[t]{14}{*}{ Ttho-4* } & 134 & 0.013 & 0.013 & 0.000 \\
\hline & 142 & 0.051 & 0.040 & 0.053 \\
\hline & 144 & 0.333 & 0.329 & 0.263 \\
\hline & 146 & 0.205 & 0.303 & 0.171 \\
\hline & 148 & 0.077 & 0.066 & 0.105 \\
\hline & 150 & 0.141 & 0.066 & 0.105 \\
\hline & 152 & 0.038 & 0.132 & 0.158 \\
\hline & 154 & 0.013 & 0.013 & 0.026 \\
\hline & 156 & 0.064 & 0.000 & 0.026 \\
\hline & 158 & 0.013 & 0.000 & 0.013 \\
\hline & 160 & 0.000 & 0.000 & 0.013 \\
\hline & 162 & 0.038 & 0.000 & 0.039 \\
\hline & 164 & 0.013 & 0.013 & 0.000 \\
\hline & 172 & 0.000 & 0.026 & 0.026 \\
\hline \multirow[t]{14}{*}{ Ttho- $6^{*}$} & 121 & 0.014 & 0.000 & 0.000 \\
\hline & 127 & 0.029 & 0.013 & 0.000 \\
\hline & 131 & 0.086 & 0.128 & 0.132 \\
\hline & 133 & 0.000 & 0.013 & 0.000 \\
\hline & 135 & 0.000 & 0.051 & 0.044 \\
\hline & 137 & 0.071 & 0.051 & 0.074 \\
\hline & 139 & 0.043 & 0.013 & 0.000 \\
\hline & 141 & 0.114 & 0.026 & 0.132 \\
\hline & 143 & 0.129 & 0.128 & 0.118 \\
\hline & 145 & 0.071 & 0.218 & 0.265 \\
\hline & 147 & 0.129 & 0.179 & 0.015 \\
\hline & 149 & 0.057 & 0.000 & 0.000 \\
\hline & 151 & 0.000 & 0.000 & 0.015 \\
\hline & 153 & 0.014 & 0.013 & 0.000 \\
\hline
\end{tabular}

Table 4. (continued)

\begin{tabular}{|c|c|c|c|c|}
\hline \multirow[b]{2}{*}{ Locus } & \multirow{2}{*}{$\begin{array}{c}\text { Allele } \\
\text { (bp) }\end{array}$} & \multirow{2}{*}{$\frac{\text { Pacific }}{\underset{\text { Japan }}{\text { Off }}}$} & \multicolumn{2}{|c|}{ Atlantic } \\
\hline & & & $\begin{array}{l}\text { N. W. } \\
\text { Atlantic }\end{array}$ & $\begin{array}{c}\text { Medi- } \\
\text { terranean }\end{array}$ \\
\hline & 157 & 0.000 & 0.013 & 0.000 \\
\hline & 161 & 0.000 & 0.013 & 0.074 \\
\hline & 163 & 0.029 & 0.026 & 0.029 \\
\hline & 165 & 0.014 & 0.013 & 0.015 \\
\hline & 167 & 0.029 & 0.000 & 0.044 \\
\hline & 169 & 0.043 & 0.000 & 0.000 \\
\hline & 171 & 0.029 & 0.013 & 0.000 \\
\hline & 175 & 0.000 & 0.013 & 0.000 \\
\hline & 177 & 0.014 & 0.000 & 0.000 \\
\hline & 179 & 0.000 & 0.013 & 0.000 \\
\hline & 185 & 0.000 & 0.000 & 0.015 \\
\hline & 187 & 0.000 & 0.038 & 0.015 \\
\hline & 193 & 0.000 & 0.000 & 0.015 \\
\hline & 201 & 0.014 & 0.013 & 0.000 \\
\hline & 203 & 0.014 & 0.000 & 0.000 \\
\hline & 205 & 0.014 & 0.013 & 0.000 \\
\hline & 215 & 0.014 & 0.000 & 0.000 \\
\hline & 217 & 0.014 & 0.000 & 0.000 \\
\hline & 219 & 0.014 & 0.000 & 0.000 \\
\hline \multirow[t]{19}{*}{ Ttho- $7^{*}$} & 180 & 0.000 & 0.000 & 0.014 \\
\hline & 182 & 0.000 & 0.014 & 0.000 \\
\hline & 198 & 0.088 & 0.041 & 0.042 \\
\hline & 200 & 0.138 & 0.027 & 0.000 \\
\hline & 202 & 0.025 & 0.054 & 0.000 \\
\hline & 204 & 0.050 & 0.027 & 0.083 \\
\hline & 206 & 0.025 & 0.054 & 0.153 \\
\hline & 208 & 0.025 & 0.176 & 0.111 \\
\hline & 210 & 0.000 & 0.027 & 0.097 \\
\hline & 212 & 0.000 & 0.027 & 0.000 \\
\hline & 214 & 0.025 & 0.027 & 0.028 \\
\hline & 216 & 0.013 & 0.014 & 0.111 \\
\hline & 218 & 0.013 & 0.135 & 0.097 \\
\hline & 220 & 0.188 & 0.297 & 0.181 \\
\hline & 222 & 0.150 & 0.041 & 0.069 \\
\hline & 224 & 0.113 & 0.041 & 0.014 \\
\hline & 226 & 0.113 & 0.000 & 0.000 \\
\hline & 228 & 0.025 & 0.000 & 0.000 \\
\hline & 230 & 0.013 & 0.000 & 0.000 \\
\hline
\end{tabular}

\section{Ttho-7*}

\section{Albacore}

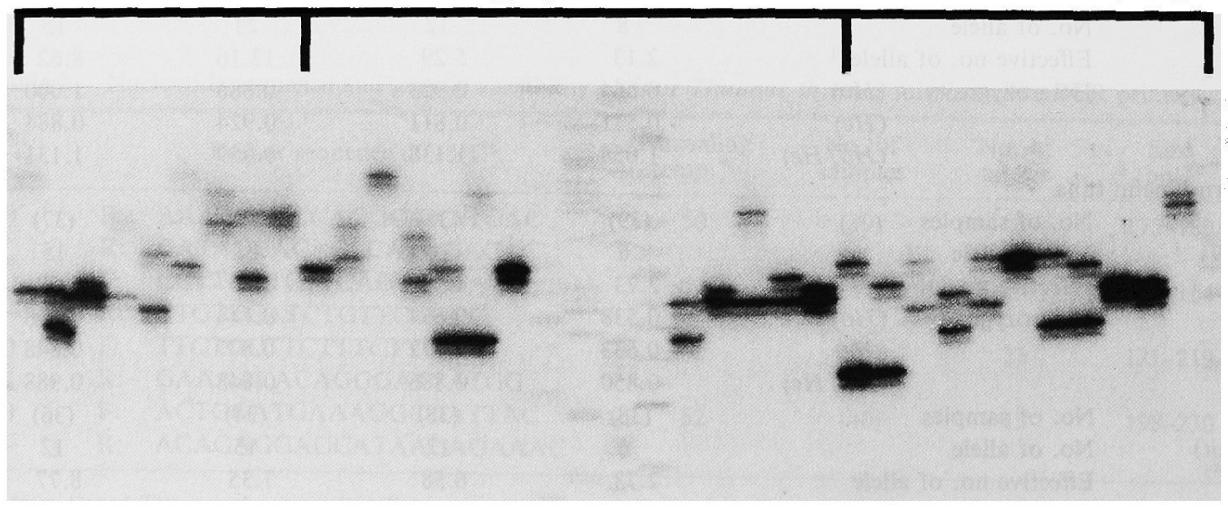

Fig. 3. Microsatellite electrophoretic pattern of $T$ tho- $7^{*}$ locus from albacore, bigeye tuna and yellowfin tuna. The size standard is a sequence ladder of M13 mp18. 
Table 5. Genetic variability for 4 microsatellite loci surveyed for tuna species used in the study

\begin{tabular}{|c|c|c|c|c|c|c|}
\hline & & Ttho-I $I^{*}$ & $T t h o-4^{*}$ & Ttho-6* & Tho- $7^{*}$ & Mean \\
\hline \multicolumn{7}{|l|}{ Albacore } \\
\hline \multirow{6}{*}{$\begin{array}{l}\text { E. Australia } \\
\left(18^{\circ}-20^{\circ} \mathrm{S}, 154^{\circ}-155^{\circ} \mathrm{E}\right)\end{array}$} & No. of samples & (31) & (32) & (31) & (32) & \\
\hline & No. of allele & 7 & 15 & 7 & 14 & 10.8 \\
\hline & Effective no. of allele*1 & 3.62 & 7.14 & 2.34 & 8.93 & 5.51 \\
\hline & \multirow{4}{*}{$\begin{array}{ll}\text { Heterozygosity } & (\mathrm{Ho}) \\
& (\mathrm{He}) \\
& (\mathrm{Ho} / \mathrm{He})\end{array}$} & 0.871 & 0.688 & 0.548 & 0.906 & 0.753 \\
\hline & & 0.724 & 0.860 & 0.573 & 0.888 & 0.761 \\
\hline & & 1.203 & 0.800 & 0.956 & 1.020 & 0.995 \\
\hline \multicolumn{6}{|l|}{ Bigeye tuna } & \\
\hline \multirow{6}{*}{$\begin{array}{l}\text { Of Philippines } \\
\text { (Celebes Sea) }\end{array}$} & No. of samples & (32) & (31) & (16) & (26) & \\
\hline & No. of allele & 12 & 10 & 22 & 18 & 15.5 \\
\hline & Effective no. of allele & 2.24 & 5.18 & 17.54 & 11.76 & 9.18 \\
\hline & \multirow[t]{3}{*}{ Heterozygosity } & 0.563 & 0.806 & 1.000 & 0.923 & 0.823 \\
\hline & & 0.554 & 0.807 & 0.943 & 0.915 & 0.805 \\
\hline & & 1.016 & 0.999 & 1.060 & 1.009 & 1.021 \\
\hline \multicolumn{7}{|l|}{ Yellowfin tuna } \\
\hline \multirow{6}{*}{$\begin{array}{l}\text { Off Philippines } \\
\text { (Celebes Sea) }\end{array}$} & No. of samples & (31) & $(25)$ & $(23)$ & (24) & \\
\hline & No. of allele & 7 & 9 & 5 & 16 & 9.3 \\
\hline & Effective no. of allele & 3.36 & 4.48 & 1.38 & 11.64 & 5.22 \\
\hline & \multirow[t]{3}{*}{ Heterozygosity } & 0.581 & 0.880 & 0.217 & 0.792 & 0.618 \\
\hline & & 0.702 & 0.777 & 0.274 & 0.914 & 0.667 \\
\hline & & 0.828 & 1.133 & 0.792 & 0.867 & 0.905 \\
\hline
\end{tabular}

${ }^{*}:=1 /(1-H e)$.

Thunnus tuna species without modifying PCR condition. Highly polymorphic profiles in a locus (Ttho- $7^{*}$ ) of these three speceis are shown in Fig. 3, and genetic variability indices at four loci are presented in Table 5. Notably low variation was observed in Ttho- $6^{*}$ of yellowfin tuna sample, in which the number of alleles was 5 and observed heterozygosity (ho) was 0.217 . Whereas, relatively to highly polymorphic patterns were observed in the other loci of yellowfin tuna and in all loci in the other species, in which observed heterozygosity (ho) ranged from 0.548 at Ttho- $\sigma^{*}$ of albacore sample to 1 at $T$ tho- $6^{*}$ of bigeye tuna sample. Mean heterozygosity $(\mathrm{Ho}$ ) was highest in bigeye tuna sample $(0.823)$ followed by albacore $(0.753)$, and that of yellowfin tuna was lowest $(0.618)$.

\section{Discussion}

The four sets of primers designed to amplify microsatellite loci of Pacific northern bluefin tuna were clearly demonstrated to be applicable for other congeneric tuna species. These phenomena are observed also in the former analysis of genus Thunnus and other scomber fishes. ${ }^{7}$ Successful cross-amplification of microsatellites among these closely related species suggests that these microsatellites have been conserved in the homologous DNA regions no matter how the levels of variation have differentiated. Ward et al. ${ }^{17)}$ investigated genetic variation of Pacific northern bluefin tuna population $(\bar{n}=29)$ using 35 allozyme gene loci. Of 8 loci found to be variable, relatively high polymorphism $\left(P_{.90}\right)$ was observed only in 3 loci, in which expected heterozygosity ranged from 0.384 to 0.523 . Maximum number of alleles per locus was 3 in their allozyme analysis, while that in the present study was 23 . Elliott and Ward ${ }^{18)}$ also investigated allozyme variation in albacore, bigeye and yellwofin tunas. In a few loci showing relatively high variation, they found expected heterozygosity ranging from 0.295 to 0.619 and number of alleles per lo- cus ranging from 2 to 5 . Thus, it appeared that microsatellite loci may harbor a much larger amount of genetic variation than allozyme gene loci. Extremely low genetic variability of microsatellites shown by number of allele and heterozygosity has been reported in endangered species $^{(9)}$ and inbreeding population. ${ }^{20)}$ The levels of length variations observed in Thunnus tuna species are much higher than these endangered or inbreeding populations, and comparable with those found in other wild fish populations such as Atlantic cod $(H e=0.757)^{\text {s) }}$, red sea bream $\left.(H e=0.849)^{9}\right)$, Japanese flounder $(H e=0.875)^{21)}$ and ayu $(H e=0.784){ }^{19)}$ Therefore, these tuna species may not be categorized as endangered or inbred species at the genetic variability point of view.

Broughton and Gold ${ }^{7}$ found that differences between Pacific and Mediterranean northern bluefin tuna were not significant for two loci Tth 16 and 26. In our study, we observed the larger genetic divergence between Pacific and Atlantic samples in all of the loci exanined. The phylogenetic topology of separation between Pacific and Atlantic northern bluefin tunas obtained with UPGMA is supported by high bootstrap value and is congruent with previous $\mathrm{mtD}$ NA analysis. ${ }^{22,23)}$ Another concern is to assess genetic heterogeneity within Atlantic northern bluefin tuna population, by which one might evaluate genetic relationships between putative western and eastern stocks. Microsatellites found in this study were considerably polymorphic but detected little differentiation between N. W. Atlantic and Mediterranean samples. Much larger sample size might be necessary for comparing local samples when using highly polymorphic gene markers. Otherwise, standard sample such as larvae or juveniles from spawning ground in Mediterranean and Gulf of Mexico must be analyzed using these microsatellite genetic markers. 


\section{References}

1) P. H. Edmunds and J. I. Sammons: Genetic polymorphism of tetrazolium oxidase in bluefin tuna, (Thunnus thynnus) from the western North Atlantic. J. Fish. Res. Bd. Can., 28, 1053-1055 (1971).

2) P. H. Edmunds and J. I. Sammons: Similarity of genetic polymorphism of tetrazolium oxidase in bluefin tuna (Thunnus thynnus) from the Atlantic coast of France and the western North Atlantic. J. Fish. Res. Bd. Can., 30, 1031-1032 (1973).

3) R. D. Ward, N. G. Elliott, and P. M. Grewe: Allozyme and mitochondrial DNA variation in yellowfin tuna (Thunnus albacares) from the Pacific Ocean. Mar. Biol., 118, 531-539 (1995).

4) J. L. Weber and P. E. May: Abundant class of human DNA polymorphisms which can be typed using then polymorphic DNA markers. Am. J. Hum. Genet., 44, 388-396 (1989).

5) A. L. Brooker, D. Cook, P. Bentzen, J. M. Wright, and R. W. Doyle: Organization of microsatellites differs between mammals and cold-water teleost fishes. Can. J. Fish. Aquat. Sci., 51, 19591966 (1994).

6) P. Jarne and P. J. L. Lagoda: Microsatellites, from molecules to populations and back. Trends in Ecology and Evolution, 11, 424429 (1996).

7) R. E. Broughton and J. R. Gold: Microsatellite development and survey of variation in northern bluefin tuna (Thunnus thynnus). Mol. Mar. Biol. Biotechnol., 6, 308-314 (1997).

8) A. S. Harris, S. Bieger, R. W. Doyle, and J. M. Wright: DNA fingerprinting of tilapia, Oreochromis niloticus, and its application to aquaculture genetics. Aquaculture, 92, 157-163 (1991).

9) M. Takagi, N. Taniguchi, D. Cook, and R. W. Doyle: Isolation and characterization of microsatellite loci from red sea bream Pagrus major and detection in closely related species. Fisheries Sci., 63, 199-204 (1997).

10) J. Sambrook, E. F. Fritsch, and T. Maniatis: Molecular Cloning, Cold Springer Harbor Laboratory Press, New York, 1989, pp. 6.45 .

11) C. Yanisch-Perron, J. Vieira, and J. Messing: Improved M13 phage cloning vectors and host strains: nucleotide sequences of the M13 mp18 and pUC 19 vectors. Gene, 33, 103-119 (1985).

12) J. B. Shaklee, F. W. Allendorf, D. C. Morizot, and G. S. Whitt: Gene nomenclature for protain-coding loci in fish. Trans. Am. Fish. Soc., 119, 2-15 (1990).

13) S. W. Guo and E. A. Thompson: Performing the exact test of Hardy-Weinberg proportion for multiple alleles. Biometrics, $\mathbf{4 8}$, 361-367 (1992).

14) S. Schneider, J.-M. Kueffer, D. Roessli, and L. Excoffier: Arlequin version 1.1, University of Geneva, Switzerland, 1997.

15) M. Nei: Estimation of average heterogeneity and genetic distance from a small number of individuals. Genetics, 89, 583-590 (1978).

16) J. Felsenstein: Phylip version $3.5 \mathrm{c}$, University of Washington, Seattie, 1989.

17) R. W. Ward, N. J. Elilott, and P. M. Grewe: Allozyme and mitochondrial DNA separation of Pacific northern bluefin tuna (Thunnus thynnus orientalis) from southern bluefin tuna (Thunnus maccoyii). Mar. Freshwater Res., 46, 921-930 (1995)

18) N. G. Elliott and R. D. Ward: Genetic relationships of eight species of Pacific tunas (Teleostei: Scombridae) inferred from allozyme analysis. Mar. Freshwater Res., 46, 1021-1032 (1995).

19) M. Takagi, E. Shoji, and N. Taniguchi: Microsatellite DNA polymorphism to reveal geographical divergence in ayu, Plecoglossus altivelis. Fisheries Sci., 65, 507-512 (1999).

20) N. Taniguchi, M. Takagi, and S. Matsumoto: Genetic evaluation of quantitative and qualititative traits of hatchery stocks for aquaculture in red sea bream. Bull. Natl. Res. Inst. Aquacult., 3, Suppl., 35-41 (1997).

21) M. Takagi, K. Yoshida, and N. Taniguchi: Isolation of microsatellite loci from Japanese flounder Paralichthys olivaceus and detection of PCR fragments with simple Non-RI methods. Fisheries Sci., 65, 486-487 (1999).

22) S. Chow and S. Inoue: Intra- and interspecific restriction fragment length polymorphism in mitochondrial genes of Thunnus tuna species. Bull. Nat. Res. Ins. Far Seas Fish., 30, 207-225 (1993).

23) S. Chow and $\mathrm{H}$. Kishino: Phylogenetic relationships between tuna species of the genus Thunnus (Scombridac: Teleostei): Inconsistent implications from morphology, nuclear and mitochondrial genomes. J. Mol. Evol, , 41, 741-748 (1995). 